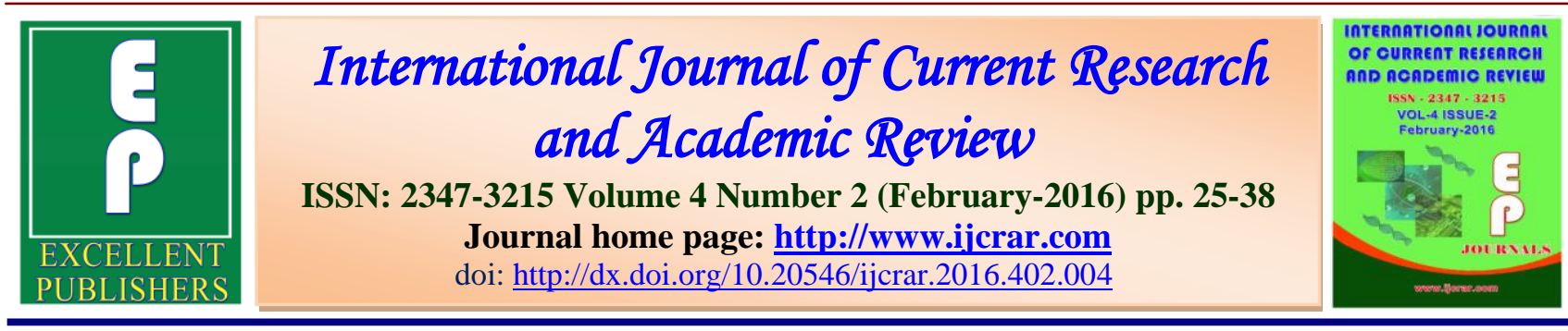

\title{
Permaculture in Asia and the Pacific: A path towards Sustainability
}

\section{Meenakshi Sinha Swami ${ }^{1}$, Kavita $\operatorname{Singh}^{2} *$ and S. P. Srivastava ${ }^{3}$}

${ }^{1}$ Dr. Meenakshi Sinha Swami, Assistant Professor of Economics, Department of Economics, M.S. College for Women, University of Delhi, New Delhi, India

${ }^{2}$ Department of Environmental Studies, M.S. College for Women, University of Delhi,

New Delhi, India

${ }^{3}$ Department of Economics, Faculty of Social Science, Dayalbagh Educational Institute, Dayalbagh, Agra, India

\section{*Corresponding author}

\begin{tabular}{|c|c|}
\hline KEYWORDS & A B S T R A C T \\
\hline $\begin{array}{l}\text { Agroecology; } \\
\text { Asia and the Pacific; } \\
\text { Ecological } \\
\text { agriculture; } \\
\text { Pemaculture } \\
\text { indicators }\end{array}$ & $\begin{array}{l}\text { Permaculture refers to permanent agriculture, or ecological agriculture, in } \\
\text { which agricultural productivity is maintained year after year by maintaining } \\
\text { soil nutrition naturally. It can be the finest solution for food security to the } \\
\text { world permanently, without degrading the soil health through excessive use } \\
\text { of inorganic nutrients, pesticides, weedicides, fertilizers etc. It conserves } \\
\text { resources by recycling waste water and human produced organic waste, into } \\
\text { the soil to maintain its nutrient levels. Practices such as monoculture should } \\
\text { be prevented and crop rotation should be practiced for sustainability and } \\
\text { resilience. This researched article explores the concept of permaculture, } \\
\text { sustainable and unsustainable practices regarding agriculture in Asia and the } \\
\text { Pacific. The research paper provides analysis data for permaculture indicators } \\
\text { for the nations in the region and finds many potholes on the pathway along } \\
\text { with solutions for sustaining agriculture in Asia and the Pacific. }\end{array}$ \\
\hline
\end{tabular}

\section{Introduction}

Permaculture, a system of land use planning that integrates concepts of ecosystem dynamics, ecologically suitable technologies and ethic of care of the earth into a comprehensive design system leading to sustaining agriculture. Large scale contamination of soil can be prevented through policies and practices which navigate towards permaculture. Worsening food security requires immediate attention and permaculture could be the answer.

This research paper reviews permaculture's concept and finds how modern agriculture practices diverge from the sustainable path. The paper also explores the significance of 
agriculture in Asia and the pacific and investigates if permaculture practices are followed in Asia and the Pacific through permaculture indicators and brings forth suggestions on how agriculture can be sustained in the region. Indian substantial initiations towards sustainable agriculture are also observed.

\section{Permaculture: The Concept}

Permaculture inducements from several disciplines including organic farming, agroforestry, integrated farming, sustainable development, and applied ecology. According to Oliver (1997), the design principles which are the conceptual foundation of permaculture were derived from the science of systems ecology and study of pre-industrial examples of sustainable land use.

The word permaculture was initially coined by Bill Mollison and Holmgren in the mid1970's to describe an "integrated, evolving system of perennial or self-perpetuating plant and animal species useful to man" (Mollison and Holmgren 1990). The core tenets of permaculture according to Mollison (1988) are:

1. Taking care of the earth such that all life systems to continue and multiply,

2. Caring of the People through access to resources necessary for their existence and

3. Sharing the Surplus, by using the output to nourish the flora and fauna, and sustain natural systems and further the above two principles.

David Holmgren brings into sharper focus the powerful and still evolving Permaculture concept he pioneered with Bill Mollison in the 1970s. The 12 permaculture design principles according to Holmgren (2002) include stressing on conservation practices in energy and land use, zero waste concept, taking feedback and designing particular solutions and integrating solutions.

A more current definition of permaculture, which reflects the expansion of focus implied in Permaculture One which relates to "Consciously designed landscapes which mimic the patterns and relationships found in nature, while yielding an abundance of food, fiber and energy for provision of local needs" (Holmgren 1997).

According to Ferguson \& Taylor (2014) agro ecologists look beyond the scientific field and try to work in partnership with traditional producers and agro ecological movements. In 1980 Mollison stated (Holler and Jeanne 1980) that the essence of permaculture was to "apply the principles of environment science to our production systems". Key features include use of compatible perennials; non-invasive planting techniques; emphasis on biodiversity; specifically adaptable to local climate, landscape, and soil conditions; highly productive output of edibles.

Permaculture farm is created in relation to the larger environment; it is itself an "ecological system nested in the web of life" (Frey 2011). Many practical examples exist from Dawborn \& Smith (2011), Holzer \& Sapsford-Francis (2010) and practices propagated by Morrow \& Allsop (2010), Hemenway (2001), Burnett (2008), Bell (2004), Whitefield (1993) etc. set an example.

\section{Permaculture Exploration in Asia and the Pacific}

The region predominantly follows intensive agriculture practices which are unsustainable. 
Permaculture aspect can be evaluated from the following indicators:

\section{Positive Permaculture Indicators}

Conservation agriculture area $(>30 \%$ ground cover) as a \% of Agricultural Land

Organic Agricultural area as percentage of Agricultural Area

Average Carbon Content in the Topsoil as a percentage in weight

\section{Negative Permaculture Indicators}

Pesticides as Active Ingredient used in Arable Land \& Permanent Crops

Water withdrawal for Agricultural Use as percentage of Total Water Withdrawal

\section{Positive Permaculture Indicators}

These indicators are beneficial for ecological and sustainable agriculture.

\section{Conservation of Agriculture Area}

Conservation of agriculture area is expected to help in resource-saving agricultural crop production along with acceptable profits. It can help in high and sustained production levels while conserving the environment concurrently.

Conservation Agriculture follows three key principles: practicing minimum mechanical soil disturbance (essential for sustaining minerals within the soil, checking erosion, and conserving water), managing the top soil to create a permanent organic soil cover (allowing the growth of organisms within the soil structure), and practicing crop rotation with more than two crop species. Tillage practice is an important indicator because any disturbance of soils may enhance turnover of nutrients and thereby increase the potential risk of loss of, for example, nitrogenous compounds and phosphorus through surface runoff and soil erosion (FAOSTAT, 2015).

From table 1 it can be assessed that Asia is much below on conservation of agriculture area at $0.29 \%$ of agriculture area when compared to Europe which conserves $1.17 \%$ of agriculture area. Conservation of agriculture area is important but globally and more so in Asia and the Pacific, conservation area is not a concern for most nations, though Asia and the Pacific accounts for $31.34 \%$ of the global area under agriculture.

\section{Organic Agricultural Area}

Organic agriculture is a farming system that tries to sustain the health of soils, ecosystems and people. It relies on ecological processes, biodiversity and cycles adapted to local conditions.

Organic farming excludes or strictly limits the use of artificial pesticides, fertilizers, plant growth regulators, antibiotics, genetic modified organisms (GMO) and other artificial additives, and relies on farming techniques (e.g. crop rotation, mechanical weed control such as plough), nitrogen fixation from leguminous crops, green manure crops, compost or manure fertilization, and biological pest control. High emphasis is put on environmental and wildlife protection, and animal welfare considerations. Although no unique standards have yet been defined for Organic Agriculture, IFOAM (International Federation of Organic Agriculture Movements) developed basic standards since 1980, and FAO/WHO defined standards in the Codex Alimentarius (FAOSTAT, 2015). 
Int.J.Curr.Res.Aca.Rev.2016; 4(2): 25-38

International Federation of Organic Agriculture Movements has also hosted knowledge sharing platform for agroecology based smallholder initiatives to help understand how these contribute to improving farm resilience and fighting hunger, malnutrition and poverty.

Table 2 shows organic agricultural area as percentage of agricultural area. The above data shows poor conservation of agriculture area in the region. According to FAOSTAT (2015) India has shown a drastic increase in area under organic farming from just $0.10 \%$ of agriculture area in 2005 to $0.66 \%$ in 2009 .

Surprisingly for Sri Lanka as an exception there has been a drastic reduction of organic area as percentage of agriculture area from 0.71 in 2007 to 0.12 in 2009 as it has moved towards market economy in agriculture products. Countries Indonesia, Malaysia, Nepal, New Zealand, Philippines, Korea, Vietnam has shown a significant improvement by doubling the area of organic farming since 2005.

\section{Average Carbon Content in the Topsoil}

Soil quality is defined according to the soil functions (e.g. bearing function, production function, habitat function, resources function, reactor function) and it is impossible $o$ be measured by a single parameter. However, soil organic carbon has been defined by EUROSTAT as the more appropriate indicator for soil quality. High organic carbon content corresponds to good conditions from an agro-environmental point of view (FAOSTAT 2015).

Soil quality can be assessed from organic carbon content of soils. Soil is generally affected by soil degradation processes and erosion has carbon content less than $1 \%$ in weight. On the other hand, soils with $1-10 \%$ organic carbon content have high agricultural value. Table 2 indicates and confirms that Malaysia and Indonesia have a good quality soil among other nations of the region. The countries with high pressure of populations and with large share of land under agriculture have poor quality soil with the exception of Malaysia and Indonesia.

Soil carbon is affected by global climate change, since climate change has altered temperature, precipitation, nitrogen availability and many other environmental factors, these changes are most likely to have great impact on soil carbon. Many scientists have highlighted the importance of carbon in soil carbon (C) in global C cycling. C flux between the atmosphere and terrestrial ecosystems involves both soil organic carbon (SOC) and soil inorganic carbon (SIC).The C flux between SOC pools and the atmosphere depends on biomass production, organic materials input and soil respiration (Shi et al 2012, p2287-2288)

Moreover climate warming causes soil carbon (C) loss owing to accelerated microbial decomposition that offsets increased grass productivity, therefore soil carbon is a good indicator of sustainable initiatives required. (Yue, 2015)

Following Green Revolution most Asian economies became self sufficient in food in 1970 's and 1980's, but it also lead to loss of soil fertility due to mono-cropping, pollution of water bodies, fertilizer dependent soil, resistance of insects to pesticides and water logging and salination due to improper irrigation, soil degradation (Mukherji 2009, p 9-10).

\section{Negative Permaculture Indicators}

These indicators are detrimental to ecological and sustainable agriculture 
Pesticides as Active Ingredient used in Arable Land \& Permanent Crops

Pesticides use an active ingredient either a chemical element or the micro-organism which kills or eliminates the pest, fungus or weed. Insecticides, herbicides, fungicides etc are pesticides. Application rates are expressed per hectare of agricultural land.

Pesticides play an important role in agricultural production by reducing the adverse effects of weeds, diseases and pests on crop yield and quality. Groundwater and surface water quality deteriorates with pesticide usage and has detrimental effect on terrestrial and aquatic biodiversity while pesticide residues in food and water are a risk for human health. The risk vary from one pesticide to another according to the pesticide's active principle (which may have different persistence and toxicity), management (applied volumes, application methods), and environmental conditions (soil and crop type, etc.).

As shown in Table 2 some countries have been reducing the usage of pesticides including Bangladesh which in 2007 had peaked its pesticides usage to 3.33 tonnes per 1000 hectare, but by 2009 had halved its usage. Japan has cut down on pesticide usage too, in 200 it was using 16.53 tonnes per 1000 hectare but it was found to be using 13.23 tonnes per 1000 hectare by 2009. Viet Nam hyas reduced its usage from 4.68 tonnes per 1000 hectare in 1996 to 2.17 tonnes per 1000 hectare in 2007 in 2001 itself

While China has been increasing its pesticide usage, in 2005 it was 8.84 tonnes per 1000 hectare and had doubled its usage by 2010. Malaysia has tripled its usage between 1992 and 2006 itself. Myanmar has also increased its usage substantially over the years from just 0.02 tonnes per 1000 hectare in 1990. New Zealand has increased its usage from 2.40 tonnes per 1000 hectare in 1995 to 9.66 tonnes per 1000 hectare in 2007. Thailand which was using just 1.07 tonnes per 1000 hectare in 2000 has almost quadrupled its usage to 4.11 tonnes per 1000 hectare by 2009.

\section{Water Withdrawal for Agricultural use as Percentage of Total Water Withdrawal}

Irrigation accounts for the main use of water in agriculture and one of the main uses of water resources in general. Water abstraction depends on several factors, such as crop type, irrigation technology, water prices, and climatic conditions.

Agricultural water withdrawal is a serious concern especially in arid and semi-arid areas, where water is scarce and highly variable from year to year. In dry regions it is necessary to irrigate certain crops to obtain reasonable yields. In addition to lower income for the farmer, low yields indicates less fertilizer nitrogen removed from the fields with harvested crops, and thereby leaving excess nitrogen $(\mathrm{N})$ in the soil resulting in potentially higher risk for leaching during the following period. Furthermore, increased water abstraction may also cause salination and contamination of water with other pollutants (FAOSTAT, 2015).

Table 3 above indicates that many countries are not much concerned about water withdrawal though it is an environmentally sensitive issue, and as a consequence data is not consistently collected as missing data is visible in the table. Water withdrawal for agricultural use as percentage of total water withdrawal is very high for most countries in Asia and the Pacific. For India it was $90.41 \%$ in 2010 while in 2008 Bhutan was withdrawing 94.12, Philippines was 
withdrawing $82.23 \%$ of the water in 2001 while Australia was withdrawing $73.78 \%$. Table 3 shows high water consumption for agriculture in the region. Water conservation rules and regulations are unenthusiastic in the region though per capita water availability has been decreasing in the populated nations. Agriculture is the primary user of water in Asia and the Pacific. Asia presently uses approximately $73 \%$ of the 2,664 cubic kilometers $\left(\mathrm{Km}^{3}\right)$ of water the world withdraws for agriculture annually (Mukherji 2009, p5-6). Moreover most Asian countries, agriculture is the biggest user of water and can reach up to $90 \%$ of total national water consumption (Bird, Arriens and Custodio, 2009, p6-7). Asia consists of $70 \%$ of the more than 277 million hectares of global irrigated land, but irrigation systems in 1960's and 1970's were designed for mainly staple cereals, as Asia was progressing towards self sufficiency in food grains (Mukherji 2009, p2-5).

Presently irrigation schemes are performing much below the requirement in Asia and millions of farmers have subsequently taken to investing in pumps to extract water from shallow acquifiers wherever required.

The irrigation scene has become dominated by farmer owned boreholes and pumps. This is leading to over-exploitation of ground water in many areas. The face of Asian irrigation has changed from state-controlled irrigation to that of individual -centred irrigation. The problem of feeding Asia's millions coupled with higher food prices is leading to renewed interest in irrigation. Without sidelining the environment concerns the challenge for policy makers is to increase investment in irrigation with minimum disruption to natural water flows, biodiversity and ecosystem services. (Mukherji 2009, p5-6).

\section{Significance of Agriculture in Asia and} the Pacific

Asia has been predominantly dependent on agriculture, though statistics have been changing; the population pressure on arable land is on the rise. Asia's agricultural segment faces a number of challenges with rising population leading to an alarming increase in food prices and environmental concerns. Significance of agriculture in Asia can be viewed by following facts:

Asia, the Pacific and the People's Republic of China account for $55 \%$ of the world's total agricultural production. (ADB 2009, p4)

A large population that is more than 2.2 billion people in the region relies on agriculture for their livelihoods. (ADB, 2009, p 5)

Two-thirds of the estimated 1 billion to 1.5 billion people who are food insecure and poor, live in Asia. By 2050, the world will have 2 billion more people, most living in Asia and the Pacific. The Food and Agriculture Organization of the United Nations (FAO) states that, to feed the world's poor, food production must be increased by $70 \%$ (Matsunami 2010, p 1-2).

According to ADB's static index of current national adaptive capacities many vulnerable countries lie in Asia and the pacific with Bangladesh being extremely vulnerable to climate change, while China, Nepal and Pakistan significantly vulnerable and India, South East Asia and Sri Lanka moderately vulnerable. It is an area with rising flood, cyclone and drought hotspots. (ADB 2009, p 211-214)

The region is dependent on rice production. Rice is the most important crop throughout 
Asia. Statistical estimation shows $90 \%$ of the world's production and consumption occurring in this region. (Jha 2010, p2)

Trade in food and other agricultural products is increasingly important across East and Southeast Asia, where high-income Asian economies have driven significant agricultural expansion and the People's Republic of China is expected to emerge as a major food importer. (Jha 2010, p 44-45)

Asia is the most intensively irrigated continent in the world with a third of Asia's cropland watered artificially. During 19612003 irrigated land in Asia has more than doubled, with South Asia accounting for the maximum increase in irrigated land. (Mukherji 2009)

World Bank Development report 2008 states that agriculture growth is more effective in reducing poverty than GDP growth outside farming (Mukherji 2009, p10)

Escalation of food prices in Asia is a serious concern. The stationary and deteriorating yields of rice and wheat, major crops can be ultimately linked to declining investments in agriculture. In India, public investments in agriculture have been generally the same since 2004. (Carrasco and Mukhopadhyay 2012)

Millions of risk-averse farmers, both large and small, world-wide, have determined that the returns from planting biotech crops are high, hence repeat planting is virtually $100 \%$. Three of the top ten countries cultivating biotech crops in 2013 were part of Asia. In China, 7.5 million small farmers benefited from biotech cotton and in India there were 7.3 million beneficiary farmers.(James 2013, p 1-3).

Agriculture is the main source of income and employment for the 70 percent of the world's poor who live in rural areas. Depletion and degradation of land and water are serious challenges since productivity of food and other agricultural product get affected and consequently affect sustenance of livelihoods in rural areas and urban needs (World Bank 2015).

\section{Diversion of Modern Agriculture from the Sustainable Path}

Increasing agriculture production is marred by uncertainty of short or long term consequences. According to Darell (2011) the compartmentalization of disciplines and the war against nature raged by modern agriculture is a downward spiral leading to further disruption of the natural world.

Surprisingly government and community resources are being used to destroy healthy existing vegetation. Non-indigenous vegetation has great ecological and some varieties have nutritional value which are ignored, while the adverse impacts of removal methods (e.g. herbicide) are not properly assessed. Grandiose schemes to progressively get rid of "all the weeds", overlook essential ways of saving isolated pockets of indigenous re-vegetation surviving in isolation. New ways of thinking about sustainability approaches food systems from farm to fork encompassing processing, packaging, waste and producer consumer feedback loop (Gliessman 2015, p 725)

\section{Sustainable Agriculture through Permaculture in Asia and the Pacific}

South Asia is arguably the most vulnerable region to increasing food inflation with a large segment of the population living below or near the poverty line. Recent spike in food prices have been clearly reflected across all South Asia countries. Wrong 
policies can tip segments of the population into a situation where they may not be able to meet minimum nutritional/calorific requirements (Carrasco and Mukhopadhyay 2012).

In Asia which is much under pressure on resources due to its increasing population and climate change requires following remedial intervention.

Diversity in Agriculture and maintaining field bordering wild patches surrounding the agricultural fields. Wild grasses and shrubs should be maintained for conserving biodiversity

Organic viability of the soil should be sustained through research and lessons from viable practices by many farmers in Asia.

Water should be conserved through watering practices, watershed development, recycling of water, use of environment friendly fertilizers and chemicals.

Energy used can be renewable as Asia has a rich harvest of sun and wind and water. Solar water pumps should also be propagated.

Involvement of persons through voluntary services through NGO's and Social Responsibility Acts to preserve the agricultural soil.

Use of local resources and indigenous knowledge for solutions, with active feedback of the community.

Forming cooperatives of the local agriculturists to help them sustain agriculture with regular visit from government scientists.

Setting up cottage industries, micro units which use the produce for packaging and recycling of waste generated. Modern creative and indigenous knowledge should be provided at their doorstep.

Learning from nature to Design the pattern of growth

Intensive study by scientists of the harmful effects of various practices in agriculture and dissemination of this knowledge to the grassroot level.

Figure 1 presents a basic system of sustainable agriculture dynamics, that leads to sustainable agriculture production which can be sustained year after year and provide a food secure future. Sustainable agriculture according to Meybeck (2012, p16) should focus on 1.Sustainably increasing farm productivity and income; 2. Strengthening resilience to climate change and variability and 3. Mitigating the contribution of agricultural practices to climate change through a reduction or removal of greenhouse gas emissions.

Regional cooperation among governments in Asia and the Pacific needs to be improved. Funding for Clean Development Mechanism and other carbon funds, payments for environmental services, or other mechanisms to mitigate GHGs, must be implemented by Asian development planners and policy makers, and such funds must be accessible to vulnerable people. Moreover agriculture needs to form part of international climate change negotiations. Agriculture in Asia and the Pacific can help mitigate GHG emissions with incentive mechanisms and innovative institutions, technologies, and management systems. Mitigation strategies for Asia have the potential to contribute to poverty reduction, food security, and the resilience of agroecological systems and generate significant co-benefits for soil fertility and long-term agricultural productivity. (ADB 2009, p208-209) 
Resilience is an aspect gaining ground since uncertainties due to climate change will directly and indirectly impact agricultural and food systems, and related vulnerabilities. Building resilience has become imperative according to Meybeck (2012, p7). Resilience enables examining together various domains - biophysical (ecosystems), economic, social and institutional - and scales of operation. There are potential risks and vulnerabilities and early action is needed, especially to avoid cumulative and long-term effects. Adaptive capacity of farmers and systems, both to recover from shocks and to be prepared for changes must be enhanced.

Table.1 Conservation of Agriculture Area 2011(Source: UNDP 2015 \& FAOSTAT, 2015)

\begin{tabular}{|l|lc|}
\hline Region /countries & $\begin{array}{l}\text { Conservation } \\
\text { Ground Cover } \\
\mathbf{2 0 1 1}\end{array}$ & $\begin{array}{l}\text { Agriculture Area: >30\% } \\
\text { [\% of Agricultural Area }]\end{array}$ \\
\hline Global Aggregation & & 0.22 \\
\hline Asia & & 0.29 \\
\hline Central Asia & 0.56 \\
\hline Eastern Asia & 0.49 \\
\hline Western Asia & & 0.01 \\
\hline Americas & 0.01 \\
\hline Europe & & 1.17 \\
\hline
\end{tabular}

Figure.1 Sustainable Agriculture Dynamics

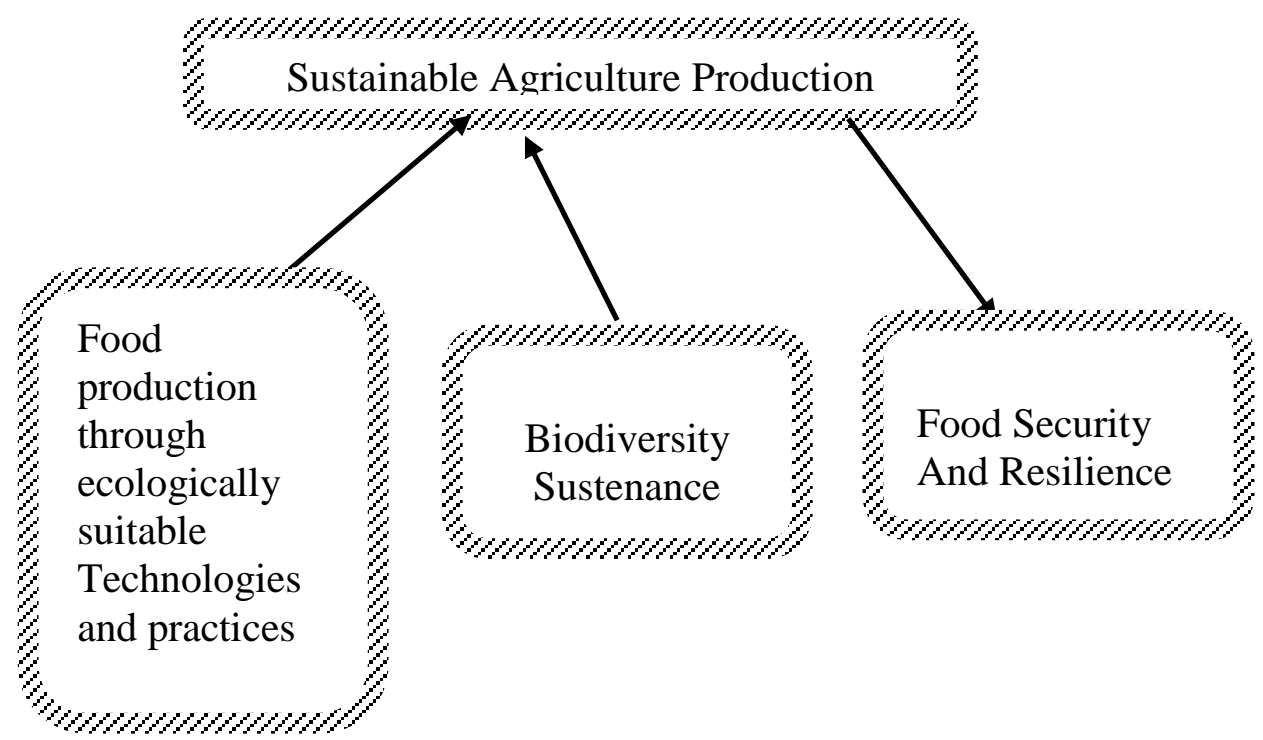


Int.J.Curr.Res.Aca.Rev.2016; 4(2): 25-38

Table.2 Organic Agricultural Area, Carbon Content in Soil and Pesticides used in Asia and the Pacific (Source: UNDP, 2015 \& FAOSTAT, 2015)

\begin{tabular}{|c|c|c|c|}
\hline $\begin{array}{l}\text { Region } \\
\text { /countries }\end{array}$ & $\begin{array}{l}\text { Organic } \\
\text { Agricultural area } \\
\text { as percentage } \\
\text { of Agricultural } \\
\text { Area } \\
2009\end{array}$ & $\begin{array}{l}\text { Average Carbon } \\
\text { Content in the } \\
\text { Topsoil } \\
\text { as a percent in } \\
\text { weight } \\
2008\end{array}$ & 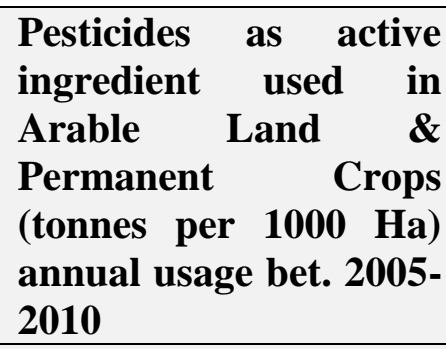 \\
\hline \multicolumn{4}{|c|}{ East Asia and the Pacific } \\
\hline Australia & 2.93 & 0.63 & 0.22 \\
\hline China & - & - & 17.81 \\
\hline Hong Kong & - & - & - \\
\hline Indonesia & 0.10 & 5.21 & 0.08 \\
\hline Japan & 0.19 & 2.28 & 13.23 \\
\hline Korea, Rep. of & 0.74 & 1.29 & 13.12 \\
\hline Malaysia & 0.02 & 3.48 & 5.20 \\
\hline Myanmar & 0.00 & 1.26 & 0.75 \\
\hline New Zealand & 1.08 & 1.85 & 9.88 \\
\hline Philippines & 0.44 & 1.28 & - \\
\hline Singapore & - & 0.63 & - \\
\hline Taiwan & - & - & - \\
\hline Thailand & 0.14 & 1.01 & 4.11 \\
\hline Viet Nam & 0.14 & 1.26 & 2.17 \\
\hline \multicolumn{4}{|c|}{ South Asia } \\
\hline Afghanistan & 0.00 & 0.92 & - \\
\hline Bangladesh & 0.01 & 1.90 & 1.54 \\
\hline Bhutan & 0.01 & 1.15 & 0.10 \\
\hline India & 0.66 & 0.88 & 0.24 \\
\hline Maldives & - & - & - \\
\hline Nepal & 0.19 & 1.32 & 0.03 \\
\hline Pakistan & 0.08 & 0.86 & 0.27 \\
\hline Sri Lanka & 0.12 & 0.88 & 0.67 \\
\hline
\end{tabular}


Int.J.Curr.Res.Aca.Rev.2016; 4(2): 25-38

Table.3 Water Withdrawal for Agricultural Use (Source: FAOSTAT 2015 \& FAO AQUASTAT 2015)

\begin{tabular}{|c|c|c|c|c|}
\hline \multirow{2}{*}{$\begin{array}{l}\text { Region /countries } \\
\text { Year Range }\end{array}$} & \multicolumn{4}{|c|}{$\begin{array}{l}\text { Water withdrawal for agricultural use as \% } \\
\text { (percentage) of total water withdrawal }\end{array}$} \\
\hline & 1990-1995 & 1996-2000 & 2001-2005 & 2006-2010 \\
\hline \multicolumn{5}{|c|}{ East Asia and the Pacific } \\
\hline Australia & - & 69.85 & 73.78 & - \\
\hline China & 83.00 & 71.00 & 64.61 & - \\
\hline Indonesia & 93.14 & 81.87 & - & - \\
\hline Japan & 64.11 & 66.11 & 63.13 & - \\
\hline Korea, Rep. of & - & - & 62.03 & - \\
\hline Malaysia & 82.02 & 45.72 & 26.96 & 22.41 \\
\hline Myanmar & 95.58 & 88.99 & - & - \\
\hline New Zealand & 50.21 & - & 74.32 & \\
\hline Philippines & - & - & 83.13 & 82.23 \\
\hline Thailand & - & - & - & 90.37 \\
\hline Vietnam & - & - & 94.78 & - \\
\hline \multicolumn{5}{|c|}{ South Asia } \\
\hline Afghanistan & 97.00 & - & - & - \\
\hline Bangladesh & - & - & - & 87.82 \\
\hline Bhutan & - & - & - & 94.12 \\
\hline India & 92.00 & 91.48 & - & 90.41 \\
\hline Maldives & - & - & - & 0.00 \\
\hline Nepal & - & 97.49 & - & 98.11 \\
\hline Pakistan & 96.79 & 94.26 & - & 93.95 \\
\hline Sri Lanka & 96.01 & 92.24 & 87.34 & - \\
\hline
\end{tabular}

Permaculture is a solution to the problem of food insecurity. This can strengthen the objectives of the FAO Integrated Food Security Support System which are to 1). Develop capacities of regional, national and local institutions and stakeholders in formulating, monitoring and evaluating programmes for food and nutrition security; 2). Provide technical assistance in support of national and regional programmes for food and nutrition security and 3) Facilitate knowledge sharing and communication of lessons learned from implementing programmes for food and nutrition security. Permaculture if practiced locally or stimulated by the national governments and world bodies can bring in sustainability and resilience in agriculture.

\section{Indian Mission towards Sustainable Agriculture}

Government of India is implementing policies/missions aiming various threats faced by agriculture. Some of the substantial initiations are National Food Security Mission, Mission for Integrated Development of Horticulture, National Mission for Sustainable Agriculture, Paramparagat Krishi Vikas Yojana to stimulate organic farming practices, Pradhan Mantri Krishi Sinchayee Yojana to stimulate efficient irrigation practices and National Mission on Agricultural Extension \& Technology as indicated in India's intended nationally determined contribution towards climate justice. 
1) The National Mission on Sustainable Agriculture (NMSA) targets at enhancing food security and protection of resources such as land, water, biodiversity and genetics. The mission centers on new technologies and practices in cultivation, genotypes of crops that have enhanced $\mathrm{CO}_{2}$ fixation potential, which are less water consuming and more climate resilient. India has established 580 district level (covering many states) contingency plans based on early warning systems and other weather forecasting systems.

2) Government of India approved a mega project called the National Initiative on Climate Resilient Agriculture (NICRA). Its four main components include Natural Resource Management, improving crop production, livestock and fisheries and institutional interventions.

3) A Scheme has been propelled to provide in mission mode Soil Health Card to every farmer. Additionally, 100 mobile soil-testing laboratories have been established across the country.

4) National Agroforestry Policy (NAP) of India targets at encouraging and expanding tree plantation in complementarity and integrated manner with crops and livestock. It will benefit protect and stabilize ecosystems, and promote resilient cropping and farming systems to minimize the risk during life-threatening climatic events. It will also complement achieving the target of increasing forest/ tree cover.

\section{Conclusion and Limitation}

Asia and the Pacific Region have to wake up to the realities of climate change and ensure sustainable practices for feeding the millions living in the region. Permaculture can be strengthened through subsidies or sops for practicing permaculture. There can also be a pollution tax on rich farmers for not following sustainable practices.

The major limiting factors to the potential of permaculture to contribute towards agroecological transition are firstly the general isolation of permaculture from science, both lack of scholarly research with regards to permaculture and neglect within the permaculture literature of contemporary scientific perspectives and secondly there is the absence of any systematic multisite assessment of permaculture's impacts.

This research study should also account for water stress and water consumption (water consumption relates to the amount of extracted water irretrievably lost during its use) in agriculture. Withdrawals exceeding $20 \%$ of renewable water supply have been used as an indicator of water stress and water should not be over consumed (ADB 2009, p 210).

\section{References}

ADB, (2009) Building Climate Resilience in the Agriculture Sector of Asia and the Pacific, International Food Policy Research Institute, Asian Development Bank, Philippines, ADB

Bell, Graham, (2009) The Permaculture Way, 2nd edition UK, Permanent Publications, 2004

Bird, Jeremy; Arriens, Wouter Lincklaen. and Custodio, Dennis Von. (2009) Water Rights and Water Allocation: Issues and Challenges for Asia, $A D B$ Water for All Series No.17, Philippines, Asian Development Bank, accessed on June 28 2015.,

Carrasco, Bruno and Mukhopadhyay, Hiranya. (2012) Food Price Escalation in South Asia- A 
Serious and Growing Concern, $A D B$ South Asia Working Paper Series, No. 10, Philippines, Asian Development Bank

Dawborn, Kerry and Smith, Caroline. (2011) Permaculture Pioneers : Stories From The New Frontier, Victoria, Australia, Mellidora Hepburn

FAO AQUASTAT, (2015) accessed on June 182015 ,

FAOSTAT, (2015) accessed on June 18 2015.

Ferguson, Rafter Sass and Lovell, Sarah Taylor., (2014), Permaculture for agroecology: design, movement, practice and worldview, A review, Agronomy for Sustainable Development 34 251-274

Frey, Darrell, (2011) Towards a Permanent Culture, Cp1, in Bioshelter Market Garden : A Permaculture Farm, Gabriola Island, BC New Society Publishers, $\mathrm{p}$ 4-19

Graham Burnett, (2008), Permaculture: A Beginner's Guide. (2nd ed), Essex, England, Spiralseed

Hemenway, Toby, (2001) Gaia's Garden : A Guide to Home-Scale Permaculture, Vt., Chelsea Green Pub. Company

Hollar, Larry., Malmgren,Jeanne.,and Mollison, Bill., (1980) Permaculture Activist, Mother Earth News, http://www.motherearthnews.com/ho mesteading-and-livestock/billmollison-permaculture-activistzmaz80ndzraw.aspx

Holmgren, David., (2002) Permaculture : Principles \& Pathways Beyond Sustainability, Holmgren Design Services, Hepburn, Vic.

Holmgren, Oliver., (1997) Weeds or Wild Nature, Permaculture International Journal 61 , http://www.holmgren.com.au/frames et.html?http://www.holmgren.com.au $/ \mathrm{html} /$ Writings/weeds.html
James, Clive (2013) Global status of commercialized biotech/GM crops 2013, Executive Summary, Brief 46, International Service for the Acquisition of Agri-Biotech Applications Global Status of Commercialized Biotech/GM Crops 2013, Philippines,

Jha, Shikha., Roland-Holst, David., and \& Sriboonchitta, Songsak., (2010) Regional Trade Opportunities for Asian Agriculture, ADB Working Paper Series no.191, ADB Economics, Philippines, Asian Development Bank, 2010, accessed on June $28 \quad 2015$ www.adb.org/economics

Matsunami, Katsuji., (2010) "Agriculture, Rural Development and Food", INFOCUS, April, ADB Focal Point, Regional and Sustainable Development Department, Asian Development Bank, accessed on June 282015

Meybeck, Alexandre., Lankoski, Jussi., Redfern, Suzanne., Azzu, Nadine., and Gitz, Vincent. (2012) Building Resilience for Adaptation to Climate Change in the Agriculture Sector, Proceedings of a Joint FAO/OECD Workshop 23-24 April, Food and Agriculture Organization of the United Nations Organisation for Economic Co-Operation and Development, Rome, 2012

Mollison, B. C. \& Holmgren, David., (1990) Permaculture One : A Perennial Agriculture for Human Settlements, Tagari, Australia.

Mollison, Bill. (1988) Permaculture: A Designers' Manual, Tagari Publications

Morrow, Rosemary and Allsop, Rob (2010) Earth User's Guide to Permaculture, Hampshire, U.K., Permanent 
Publication, Distributed in the USA by Chelsea Green Publ, 2nd ed,

Mukherji, Aditi., Facon, Thierry., Burke, Jacob., Fraiture, Charlotte de., Faurès, Blanka., Füleki, Jean-Marc., Giordano, Mark., Molden, David., and Shah, Tushaar., (2009) Revitalizing Asia's Irrigation: To sustainably meet tomorrow's food needs, International Water Management Institute and Food and Agriculture Organisation of the United Nations,, accessed on June 28 2015 , http://www.fao.org/nr/water/docs/Re vitalizing_Asias_Irrigation.pdf

Sepp Holzer \& Sapsford-Francis, Anna., 2010 () Sepp Holzer's Permaculture : A Practical Guide to Small-Scale, Integrative Farming and Gardening, White River Junction, Green Pub., Chelsea

Shi, Y., Baumann, F., Ma, Y., Song, C., Kühn, P., Scholten, T., and He, J.S., (2012) "Organic and inorganic carbon in the topsoil of the Mongolian and Tibetan grasslands: pattern, control and implications",
Biogeosciences, 9, doi:10.5194/bg-92287-2012,

Gliessman, Steve., (2015) A Global Vision for Food System Transformation, Agroecology and Sustainable Food System, 39: 725-726, LLC, Taylor and Francis Group, doi: 10,1080/21683565.2015.1039159

Whitefield, Patrick, (1993) Permaculture in a Nutshell, UK, Permanent Publications.

Yue, Haowei., Mengmeng Wang, Shiping Wang, Jack A Gilbert, Xin Sun, Linwei Wu, Qiaoyan Lin, Yigang Hu, Xiangzhen Li, Zhili He, Jizhong Zhou and Yunfeng Yang, "The microbe-mediated mechanisms affecting topsoil carbon stock in Tibetan grasslands", 17 February 2015, The Multidisciplinary Journal of Microbial Ecology.

UNEP, (2015), The UNEP Environmental Data Explorer and World Development Indicators (WDI-The World Bank), United Nations Environment Programme, accessed on June 182015.

\section{How to cite this article:}

Meenakshi Sinha Swami, Kavita Singh and S. P. Srivastava. 2016. Permaculture in Asia and the Pacific: A path towards Sustainability. Int.J.Curr.Res.Aca.Rev. 2016.4(2): 25-38.

doi: http://dx.doi.org/10.20546/ijcrar.2016.402.004 